\section{Neutralization of Bridge Blood Anticoagulant}

IN order to correct the deficient plasma thromboplastin generation in hæmophilia, extraordinary amounts of antihæmophilic globulin are required ${ }^{1}$. This has been attributed to the inhibitory action of Bridge anticoagulant ${ }^{2}$. The fact that the latter is characteristically absent in serum ${ }^{3}$ prompted further investigations on the changes in the concentration of this inhibitor during the process of coagulation. The results (Table 1) revealed that full activity was maintained until the clotting of fibrinogen, following which event the anticoagulant rapidly became inert. Theoretically this meant that the removal of Bridge anticoagulant may be accomplished by one of three processes; adsorption on fibrin, destruction by thrombin or inactivation by a compound formed by thrombin-fibrinogen interaction.

Table 1. THE EFFECT OF COAGULATION ON THE CONCENTRATION OF Time of testing* BRIDGE ANTICOAGULANT

$\begin{array}{lc}\text { Before clotting } & \text { Clotting time of substrate } \\ \text { (sec.) } \dagger \\ 1 \text { minute after cloting } & 23 \frac{1}{2}-25 \\ 15 \text { minutes after clotting } & 12\end{array}$
15 minutes after elotting
* Venous hxmophilic blood was rapidiy drawn and aliquots of
1.8 ml. incubated at $37^{\circ} \mathrm{C}$. At 2 -min. intervals the was stopped in one of the specimens by the addition of $0.2 \mathrm{ml}$. 3.8 peces cent sodium citrate. The activity of Bridge anticoagulant in each specimen was then estimated.

T Plasma (or serum) to be tested was treated with aluminium hydroxide and then incubated undiluted with equal volumes of factor V solution ( $5 \mathrm{mgm} . / \mathrm{ml}$. imidazole buffer $\mathrm{pH} 7 \cdot 3$ ), antihæmophilic globulin solution $(0.3 \mathrm{mgm} . / \mathrm{ml}$.), platelet suspension, imidazole buffe pH $7 \cdot 3$, diluted $(1: 10)$ normal serum and $0 \cdot 05 \mathrm{M}$ ealcium chloride. The activity of plasma thromboplastin formed after 6 min. was estimated by adding $0.1 \mathrm{ml}$. of the mixture together with $0.1 \mathrm{ml}$. $0.025 M$ calcium chloride to $0.1 \mathrm{ml}$. substrate (normal citrated plasma), recording the clotting time. Normal reagents gave 10 sec.

Further experiments were, therefore, carried out in order to test the above possibilities. Defibrination by the addition of small amounts of thrombin completely abolished the anticoagulant activity (Table 2). On the other hand, neither removal of fibrinogen by heat at $56^{\circ} \mathrm{C}$. for $3 \mathrm{~min}$., nor the addition of thrombin to heat-defribinated plasma affected the inhibitory action. This denoted that the agent responsible for the neutralization of Bridge anticoagulant is derived from the action of thrombin on fibrinogen.

Table 2. THE EFFECT OF DFFIBRINATION ON BRIUGE ANTICOAGLLANT Method of defibrination ACTIVITY Substrate clotting time

$\begin{array}{lc}\text { Method of defibrination } & \text { Substrate clotting time } \\ \text { Thrombin } & 11 \\ \text { Heat }\left(56^{\circ} \text { (.). }\right. & 24 \\ \text { Control (no defibrination) } & 25 \\ & * \text { For details see Table } 1 .\end{array}$

Methods have now been developed for the preparation of this Bridge anticoagulant neutralizing agent, free of antihæmophilic globulin, from fresh blood as well as from expired bank-blood. In vitro experiments showed that, by removing the action of Bridge anticoagulant, this material improves the action of antihæmophilic globulin ; a much smaller amount (20 per cent) of the latter factor was required for the produc tion of normal levels of plasma thromboplastin from undiluted hæmophilic plasma (unpublished work).

Research Fellow in Hæmophilia,

F. Nour-Eudin

Department of Hæmatology,

Royal Infirmary,

Manchester, 13. July 24.

${ }^{1}$ Nacfarlane, R. G., Mallam, P. C., Witts, L. J., Bidwell, L., Biggs, R. Fraenkel, G. J., Honey, G. F., and Taylor, K. B., Lancet, ii, 251 (1957).

${ }^{2}$ Nour-Eldin, F', and Wilkinson, J. F., Brit. J. Hoemat., 4, 292 (1958). Nour-Eldin, F., and Wilkinson, J. F., Nature, 180, 990 (1957). Brit.

\section{PATHOLOGY}

\section{Hereditary Absence of Spleen in the Mouse}

THE 'luxoid' mutants of the house-mouse form a small and well-defined group with striking limbdefects. In luxate ${ }^{1}(l x)$ and luxoid ${ }^{2}(l u)$ homozygotes hind-legs are often twisted, due to reduction or loss of the tibia and distortion of the fibula with associated muscular abnormalities. The femur may also be shortened and fragmented and even the pubic element of the pelvic girdle may be affected in luxates. The hind-feet may show pre-axial poly- or oligo-dactylism, the fore-feet may also be polydactylous in $l u l u$ mice. Heterozygotes may appear normal or may have preaxial triphalangy or polydactyly of the hind-feet. There are various other skeletal effects (on the number of presacral vertebræ, etc.) while the urogenital system is also involved in luxate homozygotes, with frequent hydronephrosis and hydroureter.

Among other members of this group which have recently been investigated is one in which the skeletal and other defects are decidedly more severe. T. C. Carter has shown that this 'dominant hemimelia' ( $D h)$ is close to leaden $(l n)$ in linkage group XIII'

Skeletally, $D h$ heterozygotes may be affected as severely as luxate homozygotes ${ }^{4}$ and in much the same way. Thus the hind-limbs may show the following abnormalities: (1) pre-axial triphalangy, poly-, syn-or oligo-dactyly; (2) tibial hemimelia or absence with associated fibular distortion, so that the leg is twisted and useless; (3) reduction and sometimes fragmentation of the femur; (4) reduction or even loss of the pubic element of the pelvic girdle, though this only rarely occurs. The number of sternebrre and of presacral vertebræ also tend to be reduced. Limb abnormalities are generally more severe in $D h$ homozygotes, with loss of up to three digits from the pre-axial side of the hind-foot, while the hind-leg is always greatly twisted and reduced in size. The forelimb is unaffected, however.

Visceral examination of $D h$ heterozygotes and homozygotes has revealed some interesting abnormalities. All entirely lack the spleen. This can be seen without dissection in newly born or day-old mice, when the viscera are still visible through the bodywall and the bright red colour of the spleen contrasts with the dull red of the adjacent kidney. Heterozygotes also tend to have a smaller stomach and a shorter alimentary canal than normal; moreover, they show a marked flattening of the antero-ventral part of the left kidney. Hydronephrosis and hydroureter may occur, as in $l x l x$ mice, but are not common. Lymphatic tissues other than the spleen, such as the intestinal Peyer's patches and the thymus, seem unaffected.

Dominant hemimelia is lethal when homozygous, death usually occurring within four days of birth. Homozygotes are obtained by intercrossing $D h l n /++$ mice; since these two loci are only about 5 units apart, 90 per cent of $D h D h$ offspring will also be leaden. This allows a useful check on the genotype of presumed homozygotes, since leaden homozygotes can be identified at birth by microscopical examination of the skin, when very marked clumping of pigment granules can be seen in the hair follicles.

Besides the spleen loss and limb defects already mentioned, the nine homozygotes examined so far have had serious urogenital and alimentary defects. These include severe hydronephrosis and hydroureter, the swollen ureters often joining together and ending 